\title{
FAKTOR-FAKTOR YANG MEMPENGARUHI NIAT MAHASISWA AKUNTANSI TERHADAP PROFESI AKUNTAN PUBLIK (Studi Kasus Terhadap Mahasiswa Akuntansi Di Kota Bengkulu)
}

\author{
Zahrah Indah Ferina \\ Program Studi Akuntansi Fakultas Ekonomi Universitas Dehasen Bengkulu \\ zahrah.indahferina@gmail.com
}

\begin{abstract}
ABSTRAK
Zahrah Indah Ferina; Akuntan Pulik adalah akuntan yang memberikan jasa untuk medapatkan imbalan atau honor (fee). Kebutuhan terhadap Akuntan publik di era Masyarakat Ekonomi Asean (MEA) ini semakin meningkat, maka tujuan dari penelitian ini adalah untuk menganalisis faktor-faktor yang mempengaruhi niat terhadap profesi Akuntan Publik. Faktor-faktor yang mempengaruhi niat tersebut diukur dengan variabel penghargaan finansial dan pertimbangan pasar kerja. Sampel yang digunakan dalam penelitian ini sebanyak 83 responden. Sampel diperoleh dari mahasiswa akuntansi yang telah menyelesaikan mata kuliah Auditing di Universitas Negeri dan Swasta di kota Bengkulu. Untuk menganalisis hipotesis, penelitian ini menggunakan analisis regeresi berganda. Hasil analisis menunjukkan bahwa variabel penghargaan finansial dan pertimbangan pasar kerja berpengaruh signifikan terhadap niat untuk berprofesi sebagai Akuntan Publik
\end{abstract}

\section{ABSTRACT}

Zahrah Indah Ferina; $A$ Public Accountant is an accountant who provides services to obtain rewards or fees. The need for public accountants in the era of MEA is increasing, then the purpose of this study is to factors that affect the intention to the profession of Public Accountants. Factors influencing this intention with financial rewards and considerations of labor market. The sample used in this research is 83 respondents. Samples are obtained from accounting students who have completed the Auditing courses at State and Private University in Bengkulu. To analyze the hypothesis, this study used multiple regression analysis.

The result of this research showed that financial reward and consideration of labor market has influence in career choosing as public accountant.

Key words: Accounting Student, Intention, Public Accountant

\section{LATAR BELAKANG}

Dalam menghadapi Masyarakat Ekonomi Asean (MEA) yang telah disepakati dalam Konferensi Tingkat Tinggi (KTT) Association of Southeast Asian Nation (ASEAN) ke 9 tahun 2003, Indonesia tidak hanya dihadapi oleh kesiapan dalam memproteksi produk dalam negerinya saja akan tetapi juga pada sisi dunia ketenagakerjaan. Adapun defenisi ketenagakerjaan menurut Undang-Undang No 13 Tahun 2013 adalah segala hal yang berhubungan dengan tenaga kerja pada waktu sebelum, selama dan sesudah masa kerja. Walaupun warga negara Indonesia dalam UUD 1945 dijamin kesejahteraanya sehingga memiliki hak atas pekerjaan dan penghidupan yang layak akan tetapi dalam kenyataannya dihadapkan dengan keterbatasan lapangan pekerjaaan.

Mahasiswa dituntut untuk memiliki skill atau kemampuan yang cekatan untuk menghadapi persaingan ini. Beberapa kesempatan karir telah tersedia terutama bagi mahasiswa akuntansi diantaranya akuntan publik. Menurut Warrent (2016) kebutuhan atas akuntan melebihi jumlah lulusan dalam pasar tenaga kerja. Kebutuhan individu yang mempunyai latar belakang ilmu akuntansi meningkat didalam bidang industri dan pemeritahan. Akuntan di Indonesia sebenarnya telah siap oleh persaingan MEA, hal ini dikarenakan mereka terus meng- upgrade pendidikan profesinya untuk mutu audit yang tidak kalah dengan dunia internasional.

Profesi akuntan publik memiliki tanggung jawab yang tidak hanya terhadap pemberi jasanya (klien) saja akan tetapi mempunyai tanggung jawab terhadap kepentingan publik. Akuntan yang profesional mematuhi etika profesi dalam proses memperoleh hasil audit, antara lain integritas, objektivitas, kompetensi dan kehati-hatian profesional, kerahasiaan, perilaku profesional (Arens, 2008).

Untuk itu, diharapkan profesi ini merupakan profesi yang sangat diminati oleh para mahasiswa akuntansi setelah menyelesaikan pendidikan formal di Universitas. Adapun niat yang dimaksud adalah suatu rasa dan suatu ketertarikan pada sesuatu hal/aktivitas, tanpa ada yang menyuruh dan timbul tidak secara tiba-tiba atau spontan, melainkan timbul akibat partisipasi, pengetahuan dan kebiasaan (Slameto, 
2010:57). Penelitian ini meneliti beberapa faktor yang dapat mempengaruhi niat mahasiswa akuntansi terhadap profesi akuntan publik antara lain faktor penghargaan finansial, dan pertimbangan pasar kerja.

\section{LANDASAN TEORI Niat Perilaku (Behavioral Intention)}

Niat didefenisikan sebagai keinginan untuk melakukan sesuatu, bersifat tidak selalu statis (dapat berubah). Menurut Jogiyanto (2008) niat berhubungan dengan perilaku-perilaku atau tindakan-tindakan volitional dan dapat memprediksi mereka dengan akurasi yang tinggi akan tetapi dapat berubah menurut waktu. Semakin lebar interval waktu, semakin mungkin terjadi perubahan-perubahan pada niat.

Perilaku (behavior) menurut Kamus Besar Bahasa Indonesia (KBBI) adalah tanggapan atau reaksi individu terhadap rangsangan atau lingkungan. Perilaku manusia adalah sebagai suatu fungsi dari interaksi antara person atau individu dengan lingkungannya. Perilaku manusia berbeda satu sama lain, dan perilakunya adalah ditentukan oleh masing-masing lingkungannya yang memang berbeda.

Menurut Jogiyanto (2008) Niat perilaku adalah suatu keinginan (niat) seseorang untuk melakukan suatu perilaku yang tertentu, atau dengan kata lain seseorang akan melakukan suatu perilaku (behavior) jika mempunyai keinginan atau niat (behavioral intention) untuk melakukannya. Niat (Intensi) memainkan peranan yang khas dalam mengarahkan tindakan, yakni menghubungkan antarapertimbangan yang mendalam yang diyakini dan diinginkan oleh seseorang dengan tindakan tertentu. Berdasarkan uraian di atas dapat disimpulkan bahwa intensi adalah kesungguhan niat seseorang untuk melakukan perbuatan atau memunculkan suatu perilaku tertentu.

\section{Profesi Akuntan Publik}

Akuntan Publik adalah akuntan yang memberikan jasa untuk medapatkan imbalan atau honor (fee) (warren, 2016). Akuntan Publk dapat dapat melakukan praktek secara individu maupun sebagai anggota kantor akuntan publik. Profesi akuntan publik dikenal dari jasa auditnya yan disediakan untuk pengguna laporan keuangan. Timbul dan berkembangnya profesi akuntan publik disuatu negara sejalan dengan timbulnya perusahaan yang berbadan hukum, akan tetapi in tidak akan berkembang jika negara tersebut masih berskala kecil.

Akuntan publik ini diatur dalam Undang-Undang Republik Indonesia Nomor 5 Tahun 2011 tentang Akuntan Publik. Akuntan Publik menurut Undang-Undang tersebut adalah seseorang yang telah memperoleh izin untuk memberikan jasa meliputi jasa asurance (Jasa audit atas informasi keuangan historis, jasa reviu atas informasi keuangan hitoris, jasa asurans lainnya), selanjutnya jasa yang berkaitan dengan akuntansi, keuangan dan manajemen. Adapun syarat mendapatkan izin menjadi akuntan publik meliputi: Memiliki sertifikat tanda lulus ujian profesi akuntan publik yang sah, berpengalaman praktik memberikan jasa, berdomisili diwilayah negara Kesatuan Republik Indonesia, memiliki Nomor Pokok Wajib Pajak (NPWP), tidak pernah dikenai sanksi administratif berupa pencabutan izin Akuntan Publik.

Akuntan publik yang telah memenuhi stadar pendidikan dan pengalaman dan persyaratan ujian dapat menjadi Certified Public Accoutants (CPAs). CPA pada umumnya melakukan jasa akuntansi umum, audit, atau jasa kosultasi perpajakan. CPA memliki gaji yang sedikit lebih tingi dibandingkan akuntan swasta.

\section{Penghargaan Finansial Profesi Akuntan Publik}

Akuntan Publik adalah akuntan yang memberikan jasa untuk medapatkan imbalan atau honor (fee) (warren, 2016). Imbalan jasa untuk akutan publik telah diatur dalam Peraturan Pengurus Nomor 2 Tahun 2016 tentang penentuan imbalan jasa audit laporan keuangan, dimana imbalan jasa adalah imbalan yang diterima oleh akuntan publik dari entitas klienya sehubungan dengan pemberian jasa audit. Ketika memberikan jasanya akuntan publik berhak mendapatkan imbalan jasa berdasarkan kesepakatan antara akuntan publik dengan entitas kliennya yang tela disepakati dalam surat perikatan.

Menurut Peraturan Pengurus Nomor Tahun 2016 metode penentuan jumlah keseluruhan imbalan jasa yaitu menggunakan:

a. Jumlah keseluruhan yang bersifat lumpsum

b. Jumlah yang ditentukan berdasarkan realisasi penggunaan jam kerja personil atau komposit tim perikatan.

c. Jumlah yang ditentukan berdasarkan realisasi penggunaan jam kerja personil atau komposit tim perikatan dengan ditentukan jumlah minimal dan/atau maksimal sesuai pagu anggaran dari entitas klien. 
Berikut indikator batas bawah tarif penagihan (Billing Rate) imbalan jasa per jam (minimum hourly charge-out rates) ditetapkan berdasarkan klasifikasi berjenjang, sebagai berikut :

Tabel 1. Gaji Profesi Akuntan di Indonesia

\begin{tabular}{|l|c|c|c|c|c|}
\hline Kategori Wilayah & Junior Auditor & Senior Auditor & Supervisor & Manager & Partner \\
\hline Jabodetabek & 100.000 & 150.000 & 300.000 & 700.000 & 1.500 .000 \\
\hline $\begin{array}{l}\text { Luar } \\
\text { Jabodetabek }\end{array}$ & 70.000 & 125.000 & 200.000 & 500.000 & 1.200 .000 \\
\hline
\end{tabular}

Sumber : Peraturan Pengurus Nomor Tahun 2016

Nilai diatas merupakan indikator minimal dapat digunakan sebagai acuan dalam penentuan imbalan jasa, namun anggota dapat menentukan nilai imbalan jasa perjam lebih tinggi sesuai dengan kondisi dan karakteristiknya yang ada. Apabila terdapat anggota menetapkan imbalan jasa dibawah nilai indikator dibawah maka hal ini berpotensi jumlah imbalan jasa yang ditetapkan tersebut tidak mencukupi untuk melaksanakan prosedur audit yang memadai sesuai kode etik, SPAP, dan ketentuan peraturan perundangundangan yang berlaku.

\section{Pertimbangan Pasar Kerja}

Pertimbangan pasar kerja adalah pertimbangan seseorang dalam memilih suatu pekerjaan, hal ini dikarenakan setiap profesi mempunyai peluang dan kesempatan berbeda-berbeda. Profesi pekerjaan yang luas lebih diminati dari pada profesi yang pasar kerjanya rendah. Kebutuhan individu yang memiliki latar belakang pendidikan akuntansi sangat dibutukan pada saat ini. Pemilihan karir melalui suatu rangkaian proses kegiatan yang terarah dan sistematis, sehingga setiap individu akan selalu mempertimbangkan segala potensi, kecerdasan, minat/bakat maupun harapan yang akan dicapainya(Ranie \& Rizal, 2012: 127).

Peran akuntan publik dalam masyarakat dan tanggung jawab sebagai akuntan publik sangat meningkat pada saat ini,contonya cakupan yang bertambah sampai pelaporan mengenai efektivitas pengendalian internal atas laporan keuangan perusahaan. Untuk itu, pertimbangan pasar kerja merupakan faktor yang dapat mempengaruhi mahasiswa akuntansi untuk menentukan apakah karir sebagai akuntan publik.

\section{KERANGKA ANALISIS}

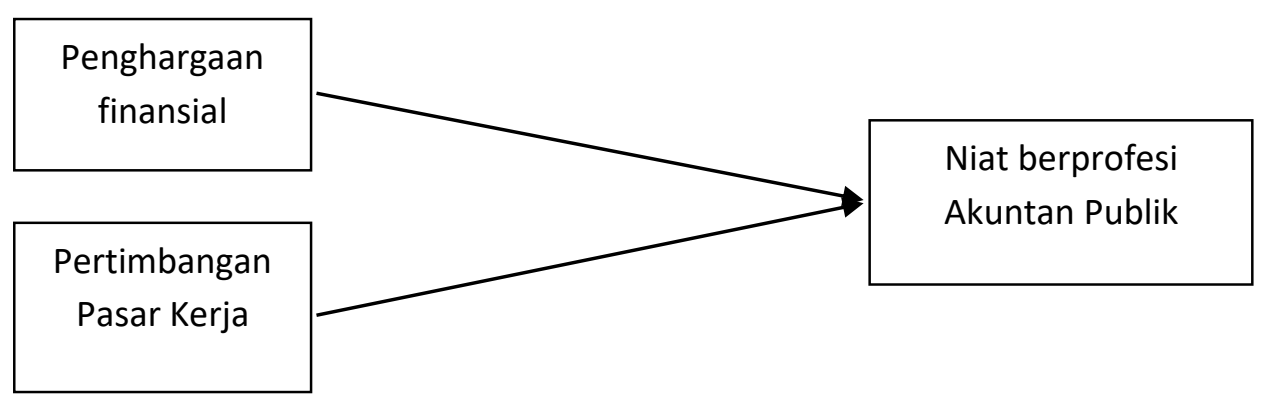

Gambar 1. Kerangka Analisis

\section{Pegembangan Hipotesis \\ Penghargaan Finansial Terhadap Niat Maasiswa Terhadap Profesi Akuntan Publik}

Penghargaan finansial merupakan balas jasa dalam bentuk uang yang diterima karyawan karena kedudukannya diperusahaan yang memberikan kontribusi dalam menapai tujuan perusahaan (Rivai, 2011) Menurut peneitian Aprilyan dan Laksito (2011) secara simultan penghargan finansial berpengaruh signifikan terhadap pemilihan karir menjadi akuntan publik begitu juga secara parisal. Alhadar (2013) secara simultan bahwa penghargaan finansial memiliki pengaruh signifikan terhadap pemilihan karir sebagai akuntan publik oleh mahasiswa akuntansi dan PPAk di Universitas Hasanuddin. Sedangkan menurut Merdekawati dan Sulistiawati (2011) penghargaan finansial tidak berpengaruh terhadap pemilihan karir akuntan publik dan non akuntan publik terhdap mahasiswa perguruan tinggi swasta di kota medan. Dari uraian di atas, dirumuskan hipotesis sebagai berikut. 
H1: Variabel Penghargaan finansial (X1) berpengaruh terhadap niat pemilihan karir sebagai akuntan publik (Y).

\section{Pertimbangan Pasar Kerja Terhadap Niat Maasiswa Terhadap Profesi Akuntan Publik}

Pertimbangan pasar kerja merupakan hal yang dipertimbangkan oleh seseorang untuk memilih suatu pekerjaan, karena setiap pekerjaan memiliki peluang yang berbeda-beda. Secara simultan faktor pertimbangan pasar kerja memiliki pengaruh signifikan terhadap pemilihan karir sebagai akuntan publik oleh mahasiswa akuntansi dan PPAk di Universitas Hasanuddin. Berbeda dengan penelitian yang dilakukan oleh Merdekawati dan Sulistyawati (2011) yang mengatakan bahwa faktor pertimbangan pasar kerja tidak berpengaruh terhadap pemilihan karir akuntan publik dan non akuntan publik terhadap mahasiswa perguruan tinggi swasta di kota medan. Dari uraian di atas, dirumuskan hipotesis sebgai berikut :

H2: Variabel pertimbangan pasar kerja (X2) berpengaruh terhadap niat pemilihan karir sebagai akuntan publik (Y).

\section{METODE PENELTIAN}

Penelitian ini dilaksanakan Universitas yang ada di Bengkulu, khususnya mahasiswa jurusan Akuntansi baik Universitas Negeri atau Universitas Swasta, yaitu Universitas Bengkulu, Universitas Dehasen, Universitas Hazairin, dan Universitas Muhammadiyah Bengkulu. Pengambilan sampel dilakukan dengan cara purposive sampling yaitu dengan kriteria tertentu. Adapun kriteria berikutnya adalah telah menempuh mata kuliah Auditing I ( Pemeriksaan Akuntansi).

Data diperoleh dengan melakukan survey dengan menyebarkan kuesioner secara langsung kepada responden. Adapun jumlah responden dalam penelitian ini sebanyak 83 partisipan yang terdiri dari 30 partisipan dari Universitas Bengkulu, 25 partisipan dari Universitas Dehasen, 15 partisipan dari Universitas Muammadiyah Bengkulu, dan 13 Universitas Hazairin . Teknik pengumpulan data primer pada penelitian adalah kuesioner. Kuesioner merupakan teknik pengumpulan data yang dilakukan dengan cara memberi seperangkat pertanyaan atau pernyataan tertulis kepada responden untuk dijawabnya. (Sugiyono, 2014). Alat analisis yang digunakan yaitu analisis regresi berganda dimana analisis ini merupakan studi mengenai ketergantungan variabel dependen dengan dua atau lebih variabel independen.

Sebelum dilakukan analisis regresi maka dilakukan pengujian instrumen dengan uji validitas dan reliabilitas. Instrumen dinyatakan valid jika hasil perhitungan koefisien korelasi menunjukkan koefesien korelasi > 0,3 (Ghozali, 2016). Suatu variabel dinyatakan reliabel jika nilai Cronbatch Alpha >0,70 ((Ghozali, 2016). Pengujian asumsi klasik yang dilakukan terdiri dari uji normalitas, multikolinieritas, dan heterokedastisitas. Uji kelayakan model (Goodness of Fit) dilakukan untuk membuktikan ketepatan fungsi regresi sampai dalam menaksir nilai aktual dengan mengukur nilai koefisien determinasi, nilai statistik F, dan nilai statistik t. Apabila hasil uji F adalah signifikan atau P value $\leq$ 0,05 maka hubungan antar variabel terikat dan model regresi yang digunakan dianggap layak uji.

Rumus penelitian regresi linier berganda adalah:

$$
\mathrm{Y}=\mathrm{a}+\mathrm{b} 1 \cdot \mathrm{X} 1+\mathrm{b} 2 \cdot \mathrm{X} 2+\mathrm{e}
$$

$$
\begin{aligned}
& \text { Keterangan: } \\
& \mathrm{Y} \quad=\text { Niat menjadi Akuntan Publik } \\
& \alpha \quad=\text { Konstanta } \\
& \beta 1-\beta 2=\text { Koefisien regresi } \\
& \mathrm{X} 1 \quad=\text { Pengakuan Profesional } \\
& \mathrm{X} 2 \quad=\text { Nilai-nilai sosial } \\
& \mathrm{E} \quad=\text { Error }
\end{aligned}
$$

Pengujian hipotesis dengan melihat tingkat signifikansi t variabel yaitu dengan membandingkan nilai signifikansi dengan alpha 5\%. Jika nilai Sig > 0,05 maka hipotesis tidak berpengaruh. Jika nilai Sig $\leq$ 0,05 maka hipotesis berpengaruh. 


\section{HASIL DAN PEMBAHASAN}

Kuesioner disebarkan kepada mahasiswa akuntansi yang telah menempu mata kuliah Akuntansi Pemeriksaan atau Auditing, baik program reguler maupun eksekutif. Kuesioner disebarkan sebanyak 110 kuesioner, jumlah kuesioner yang kembali sebanyak 83 kuesioner., kuesioner yang tidak kembali atau hilang sebanyak 16 kuesioner dan jumlah kuesioner yang gugur sebanyak 11 kuesioner. Jadi tingkat pengembalian kuesioner yang dapat diolah lebih lanjut adalah 75,45 persen atau sebanyak 83 kuesioner.

Pengujian instrumen dilakukan untuk mengetahui nlai validitas dan reliabilitas. Berdasarkan hasil uji diketahui bahwa semua indikator yang digunakan untuk menjelaskan variabel dinyatakan valid karena uji validitasnya menunjukkan nilai person correlation $>0,03$ dan nilai signifikansi $<0,05$. Dari hasil uji reliabilitas dapat diketahui bahwa semua variabel mempunyai nilai cronbach alpha $>0,70$ sehingga dapat dikatakan semua konsep pengukuran variabel-variabel yang digunakan dalam penelitian ini adalah reliabel. Untuk selanjutnya item-item pada masing-masing konsep variabel tersebut layak digunakan sebagai alat ukur dalam pengujian statistik.

Agar memperoleh hasil uji regresi linear berganda yang tidak bias, maka model penelitian ini harus memenuhi tiga asumsi klasik yaitu uji normalitas, multikolinearitas, dan heteroskedastisitas.

Tabel 2. Uji Normalitas.

\begin{tabular}{|c|c|c|}
\hline \multicolumn{3}{|c|}{ One-Sample Kolmogorov-Smirnov Test } \\
\hline & & Unstandardized Residual \\
\hline \multicolumn{2}{|l|}{$\mathrm{N}$} & 83 \\
\hline \multirow[t]{2}{*}{ Normal Parameters ${ }^{a}$} & Mean & .0000000 \\
\hline & Std. Deviation & 1.46951702 \\
\hline \multirow[t]{3}{*}{ Most Extreme Differences } & Absolute & .073 \\
\hline & Positive & .073 \\
\hline & Negative & -.047 \\
\hline Kolmogorov-Smirnov Z & & .665 \\
\hline Asymp. Sig. (2-tailed) & & .768 \\
\hline
\end{tabular}

a. Test distribution is Normal.

Sumber: Data Olahan SPSS 2017

Hasil uji normalitas menggunakan Kolmogorov-Smirnov menunjukkan nilai Asymp. Sig sebesar 0,768 yang berarti data yang digunakan telah berdistribusi normal. Hasil uji multikolinearitas menunjukkan nilai tolerance $\geq 0,10$ dan nilai Variance Inflation Factor (VIF) $\leq 10$ sehingga dikatakan tidak terdapat gejala multikolinearitas dalam penelitian ini.

\section{Tabel 3. Uji Multikolinearitas}

\begin{tabular}{|c|c|c|c|c|c|c|c|c|}
\hline \multicolumn{9}{|c|}{ Coefficients $^{\mathrm{a}}$} \\
\hline \multirow{2}{*}{\multicolumn{2}{|c|}{ Model }} & \multicolumn{2}{|c|}{ Unstandardized Coefficients } & \multirow{2}{*}{$\begin{array}{c}\text { Standardized } \\
\text { Coefficients } \\
\text { Beta }\end{array}$} & \multirow[b]{2}{*}{$\mathrm{t}$} & \multirow[b]{2}{*}{ Sig. } & \multicolumn{2}{|c|}{ Collinearity Statistics } \\
\hline & & B & Std. Error & & & & Tolerance & VIF \\
\hline & $\begin{array}{l}\text { (Constant } \\
\text { ) }\end{array}$ & 11.641 & 2.526 & & 4.609 & .000 & & \\
\hline & $\mathrm{X} 1$ & .181 & .084 & .185 & 2.142 & .035 & .998 & 1.002 \\
\hline & $\mathrm{X} 2$ & .395 & .055 & .617 & 7.149 & .000 & .998 & 1.002 \\
\hline
\end{tabular}

a. Dependent Variable: Y

Sumber: Data Olahan SPSS, 2017

Pengujian heteroskedastisitas menunjukkan nilai signifikansi untuk semua variabel lebih dari 0,05 sehingga dikatakan tidak terjadi heteroskedastisitas. Dengan demikian semua uji asumsi klasik terpenuhi. 
Tabel 4. Uji Heteroskedastisitas

\begin{tabular}{|c|c|c|c|c|c|c|}
\hline \multicolumn{7}{|c|}{ Coefficients ${ }^{a}$} \\
\hline & & Unstandardize & Coefficients & $\begin{array}{l}\text { Standardized } \\
\text { Coefficients }\end{array}$ & & \\
\hline \multicolumn{2}{|c|}{ Model } & $\mathrm{B}$ & Std. Error & Beta & t & Sig. \\
\hline \multirow[t]{3}{*}{1} & (Constant) & .588 & 1.491 & & .395 & .694 \\
\hline & $\mathrm{X} 1$ & .033 & .050 & .073 & .653 & .516 \\
\hline & $\mathrm{X} 2$ & -.002 & .033 & -.005 & -.048 & .962 \\
\hline
\end{tabular}

a. Dependent Variable: abs_res

Sumber: Data Olah SPSS 2017

Hasil pengujian selanjutnya menggunakan regresi linear berganda menunjukkan nilai Adjusted R2 sebesar 0, 390 yang berarti bahwa variabel penghargaan finansial (X1), dan variabel pertimbangan pasar kerja (X2), mampu menjelaskan 39.0\% variasi niat berkarir menjadi Akuntan Publik (Y) sedangkan sisanya sebesar $61,4 \%$ dijelaskan oleh variabel lain diluar model. Hasil uji anova atau $F$ test menunjukkan nilai signifikansi sebesar 0,000, karena nilai signifikansi $\leq 0,05$ maka model regresi dapat digunakan untuk memprediksi penghargaan finansial (X1) dan pertimbangan pasar kerja (X2) berpengaruh terhadap niat untuk menjadi Akuntan Publik (Y).

\section{Tabel 5. Hasil Uji Signifikansi Parameter Individual (Uji t)}

Coefficients ${ }^{\mathrm{a}}$

\begin{tabular}{|c|c|c|c|c|c|c|}
\hline \multirow{2}{*}{\multicolumn{2}{|c|}{ Model }} & \multicolumn{2}{|c|}{ Unstandardized Coefficients } & \multirow{2}{*}{$\begin{array}{l}\text { Standardized } \\
\text { Coefficients } \\
\text { Beta }\end{array}$} & \multirow[b]{2}{*}{$\mathrm{t}$} & \multirow[b]{2}{*}{ Sig. } \\
\hline & & B & Std. Error & & & \\
\hline \multirow[t]{3}{*}{1} & (Constant) & 11.641 & 2.526 & & 4.609 & .000 \\
\hline & $\mathrm{X} 1$ & .181 & .084 & .185 & 2.142 & .035 \\
\hline & $\mathrm{X} 2$ & .395 & .055 & .617 & 7.149 & .000 \\
\hline
\end{tabular}

a. Dependent Variable: $Y$

Sumber: Data Olah SPSS, 2017

Hasil uji t dapat dijelaskan bahwa penghargaan finansial memiliki nilai $\beta$ sebesar 0,181 dengan nilai signifikansi sebesar 0,035 lebih kecil dari 0,05 yang berarti penghargaan finansial berpengaruh positif terhadap niat mahasiswa akuntansi berkarir menjadi akuntan publik sehingga H1 diterima. Hasil penelitian ini sejalan dengan penelitian yang tela dilakukan oleh rindani (2015) yang menyatakan bahwa penghargaan finansial berpengaruh terhadap minat mahasiswa untuk berkarir sebagai akuntan publik.

Untuk variabel pertimbangan pasar kerja memiliki nilai $\beta$ sebesar 0,395 dengan nilai signifikansi sebesar 0,000 lebih kecil dari 0,05 yang berarti pertimbangan pasar kerja berpengaruh positif terhadap niat mahasiswa akuntansi berkarir menjadi akuntan publik sehingga $\mathrm{H} 2$ diterima. Hasil ini juga sejalan dengan penelitian rindani (2015) yang menyatakan ahwa pertimbangan pasar kerja berpengaruh terhadap minat mahasiswa akuntansi untuk berkarir sebagai akuntan publik.

\section{KESIMPULAN}

1. Penghargaan finansial berpengaruh positif terhadap niat mahasiswa akuntansi untuk berkarir menjadi akuntan publik, Hal ini berarti apabila Penghargaan Finansial semakin tinggi maka mengakibatkan niat mahasiswa akuntansi untuk berkarier menjadi Akuntan Publik semakin besar. Begitu pula apabila Penghargaan Finansial semakin rendah, maka niat mahasiswa akuntansi untuk berkarier menjadi akuntan publik juga menjadi kurang baik..

2. Pertimbangan pasar kerja berpengaruh positif terhadap niat mahasiswa akuntansi untuk berkarir menjadi akuntan publik. Hal ini berarti apabila Pertimbangan Pasar Kerja semakin banyak maka mengakibatkan niat Mahasiswa Akuntansi untuk Berkarier Menjadi Akuntan Publik semakin besar, begitu pula apabila Pertimbangan Pasar Kerja semakin sedikit maka niat mahasiswa akuntansi untuk berkarier menjadi Akuntan Publik juga menjadi kurang baik. 


\section{DAFTAR PUSTAKA}

Akuntan Publik yang dituangkan dalam Undang- Undang Republik Indonesia No. 5 Tahun 2011

Aprilyan, L. A., \& Laksito, H. 2011. Faktor-Faktor yang Mempengaruhi Mahasiswa Akuntansi dalam Pemilihan Karir Menjadi Akuntan Publik (Studi Empiris pada Mahasiswa Akuntansi UNDIP dan Mahasiswa Akuntansi UNIKA). Thesis, Universitas Diponegoro

Arens, Alvin A. et al. 2008. Auditing dan Jasa Assurance (Penerjemah : Herman Wibowo. Jakarta : Erlangga Ghozali, Imam. 2013. Aplikasi Analisis Multivariate dengan Program IBM-SPSS 21. Edisi 7. Semarang: Badan Penerbit UNDIP.

Jogiyanto. 2008. Analisis dan Desain Sistem Informasi : Pendekatan Terstruktur Teori dan Praktek Aplikasi Bisnis (TH.2008). Yogyakarta: Andi.

KBBI, 2016. Kamus Besar Bahasa Indonesia (KBBI).[Online] Available at: http://kbbi.web.id/pusat,[Diakses 2 Desember 2017].

Merdekawati, Dian Putri Dan Ardiani Ika Sulistyawati. 2011 "Faktor-Faktor yang Mempengaruhi Pemilihan Karir Akuntan Publik dan Non Akuntan Publik". Aset, Maret 2011, hal.9-19 Vol. 13 No. 1 ISSN 1693$928 X$

Ranie, Z. A., \& Rizal, M. 2012. Persepsi Mahasiswa Akuntansi Mengenai Lingkungan Kerja Auditor Terhadap Pilihan Karirnya Sebagai Auditor (Studi Empiris Pada Mahasiswa Akuntansi Pada Perguruan Tinggi Di Sumut). Jurnal Ilmiah Pendidikan Tinggi, Vol.5 No.3 Desember 2012 , 123-134.

Rivai, Veithzal dan Ella Jauvani Sagala. 2011.Manajemen Sumber Daya Manusia, Edisi kedua. Jakarta : Rajawali Pers.

Slameto. 2010. Belajar dan Faktor-Faktor yang Mempengaruhinya. Jakarta: Rineka Cipta

Sugiyono. 2007. Statistika Untuk Penelitian. Bandung: CV Alfabeta.

Warren, Reeve, dan Duhac. 2016. Pengantar Akuntansi. Jakarta. Salemba Empat 